\title{
Ketamine inhibits LPS-induced tumour necrosis factor-alpha and interleukin-6 in an equine macrophage cell line
}

\author{
Daniëlle P.K. LANKVELD ${ }^{a *}$, Sarah BULL ${ }^{b}$, Paul VAN DiJK ${ }^{\mathrm{a}}$, \\ Johanna FINK-GREMMELS ${ }^{\mathrm{b}}$, Ludo J. HELLEBREKERS ${ }^{\mathrm{a}}$ \\ a Section Anaesthesiology and Intensive Care, Department of Equine Sciences, \\ Faculty of Veterinary Medicine, Utrecht University, Yalelaan 12, 3584 CM, Utrecht, The Netherlands \\ ${ }^{b}$ Department of Veterinary Pharmacology Pharmacy and Toxicology, Faculty of Veterinary Medicine, \\ Utrecht University, Yalelaan 16, 3584 CM, Utrecht, The Netherlands
}

(Received 24 May 2004; accepted 5 October 2004)

\begin{abstract}
Ketamine is widely used in equine anaesthesia. Beside its anaesthetic and analgesic properties, ketamine possesses a cytokine-modulating activity. However, to date, no data are available regarding the inhibitory effect of ketamine on the cytokine response in horses. In horses, cytokines such as tumour necrosis factor-alpha (TNF- $\alpha$ ) and interleukin-6 (IL-6) play a pivotal role in the pathogenesis of equine endotoxaemia following gastrointestinal disorders. Hence, the objective of this study was to assess the influence of ketamine on LPS-induced TNF- $\alpha$ and IL- 6 formation in an equine macrophage cell line (eCAS cells). The results demonstrate a cytokinemodulating activity of ketamine in an equine cell line, suggesting a beneficial role for ketamine in the treatment of equine endotoxaemia.
\end{abstract}

ketamine / cytokine / equine endotoxaemia / eCAS

\section{INTRODUCTION}

Ketamine is a dissociative anaesthetic drug whose effect is characterised by superficial sleep combined with marked analgesia [6]. For decades, ketamine has been used for the induction and maintenance of general anaesthesia in horses $[11,12]$. More recently, it has also been used to provide postoperative analgesic support. Moreover, ketamine preserves cardiovascular function [14], from which it is advocated for anaesthesia in cardiovascular depressed patients, including horses suffering fromendotoxaemia.
Endotoxaemia is a serious complication in horses suffering from gastrointestinal disorders. Circulating endotoxins may stimulate mononuclear phagocytes to produce and release inflammatory mediators such as eicosanoids, platelet activating factor and cytokines $[1,8]$. In horses, the pro-inflammatory cytokines, tumour necrosis factor- $\alpha$ (TNF- $\alpha$ ) and interleukin-6 (IL-6), play a pivotal role in the pathogenesis of endotoxaemia following gastrointestinal disorders $[1,9]$.

It has been previously shown that ketamine modulates cytokine levels in rodents

* Corresponding author: D.P.K.Lankveld@ vet.uu.nl 
$[15,16]$ and humans $[5,7]$. However, there are no reports to date on ketamine modulating the cytokine activity in equine patients. Hence, the aim of the present study was to determine the influence of ketamine on LPS-induced TNF- $\alpha$ and IL- 6 concentration in an equine macrophage cell line. For comparison, a human monoblastoid cell line was used.

\section{MATERIALS AND METHODS}

\subsection{Chemicals}

Ketamine, lipopolysaccharide (Escherichia coli, O111:B4), phorbol myristate acetate (PMA) and methyl-thiazolyl tertrazolium (MTT) were purchased from Sigma chemicals (St. Louis, MO, USA). Foetal calf serum (FCS) was obtained from Invitrogen (Breda, The Netherlands). Alamar blue was purchased from BioSource International (Etten-Leur, The Netherlands) and horse serum (HS), obtained from clinically healthy horses, was prepared in our own laboratory, according to standard procedures.

\subsection{Cell lines and culture conditions}

Two cell lines were used: the equine bone-marrow-derived macrophage cell line (eCAS), developed by Werners et al. [20], and the human monoblastoid tumour cell line (U937 cells; ECACC No. 85011440, UK).

The eCAS cells were seeded in 24-well plates $\left(0.2 \times 10^{6}\right.$ cells $\left./ \mathrm{mL}\right)$ and incubated in RPMI 1640 medium supplemented with $20 \% \mathrm{HS}, 100 \mathrm{IU} / \mathrm{mL}$ penicillin, $100 \mu \mathrm{g} / \mathrm{mL}$ streptomycin, $2 \mathrm{mM}$ glutamine, $1 \mathrm{mM}$ sodium pyruvate and $1 \%$ non-essential amino acids for $24 \mathrm{~h}$ at $37^{\circ} \mathrm{C}, 5 \% \mathrm{CO}_{2}$ prior to testing.

The U937 cells were cultured in RPMI 1640 medium, supplemented with $10 \%$ FCS, $100 \mathrm{U} / \mathrm{mL}$ penicillin and $100 \mu \mathrm{g} / \mathrm{mL}$ streptomycin, according to the protocol described by Wang et al. [17], with minor modifications. The cells were plated in 24well plates $\left(0.2 \times 10^{6}\right.$ cells $\left./ \mathrm{mL}\right)$ and incubated at $37^{\circ} \mathrm{C}, 5 \% \mathrm{CO}_{2}$ for $24 \mathrm{~h}$. Subsequently, the cells were stimulated to differentiate along the monocyte/macrophage lineage by the addition of PMA ( $50 \mathrm{ng} /$ well) for $24 \mathrm{~h}$ at $37^{\circ} \mathrm{C}$ prior to use.

\subsection{Exposure to LPS and ketamine}

Following the initial incubation period, the medium was removed and replaced with fresh RPMI 1640 medium containing LPS $(1 \mu \mathrm{g} / \mathrm{mL})$ and ketamine at different concentrations $(0,0.36,1.8,3.6,18$ and $36 \mu \mathrm{M})$, or ketamine $(36 \mu \mathrm{M})$ alone. After 4 and $24 \mathrm{~h}$ of incubation, the supernatants were collected for TNF- $\alpha$ analysis. Samples for IL-6 analysis were taken after $24 \mathrm{~h}$ of incubation only. All samples were stored at $-70^{\circ} \mathrm{C}$ prior to analysis.

\subsection{Alamar Blue cytotoxicity assay}

Cell viability following LPS and ketamine exposure was measured using the Alamar Blue $(\mathrm{AB})$ reduction assay as described by Bull et al. [3].

\subsection{Tumour necrosis factor- $\alpha$ and interleukin- 6 bioassay}

Tumour necrosis factor- $\alpha$ concentrations in cell supernatants were measured using a porcine kidney cell line (PK-15) according to the method of Bertoni et al. [2]. Interleukin-6 concentrations were measured using a murine $\mathrm{B}$ cell hybridoma cell line (7-TD1), described by Okada et al. [13]. The TNF- $\alpha$-induced cytotoxicity in PK-15 cells and the IL-6 induced proliferation of 7-TD1 cells, were determined using the MTT assay [10]. Cytokine concentrations in supernatants were quantified by comparison of calculated $\mathrm{EC}_{50}$ values from samples with $\mathrm{EC}_{50}$ values from the TNF- $\alpha$ and IL-6 standard curve, respectively.

\subsection{Analysis of data}

All data are expressed as mean \pm standard deviation (SD) of four independent experiments carried out in duplicate. Data were analysed for statistical significance using 


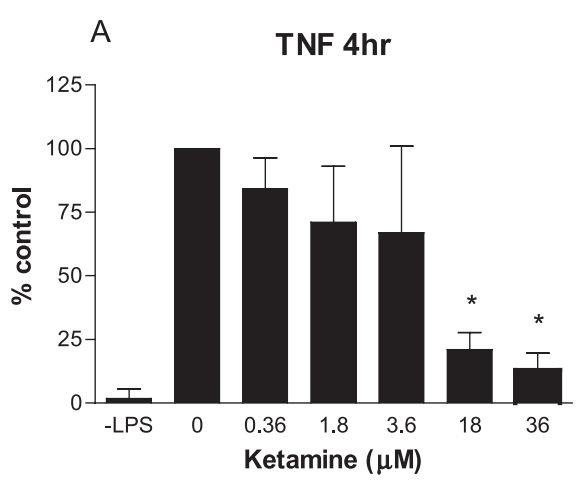

C

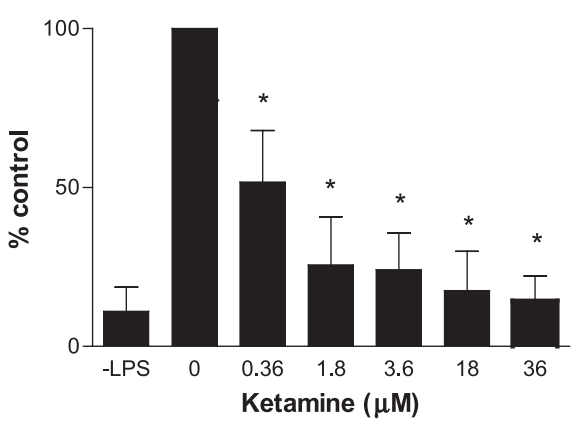

TNF 24hr

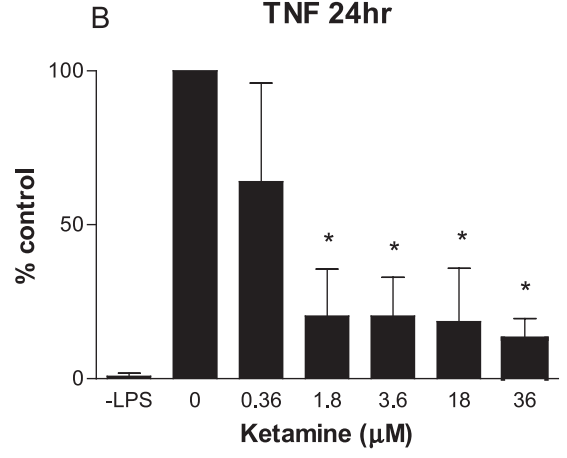

D

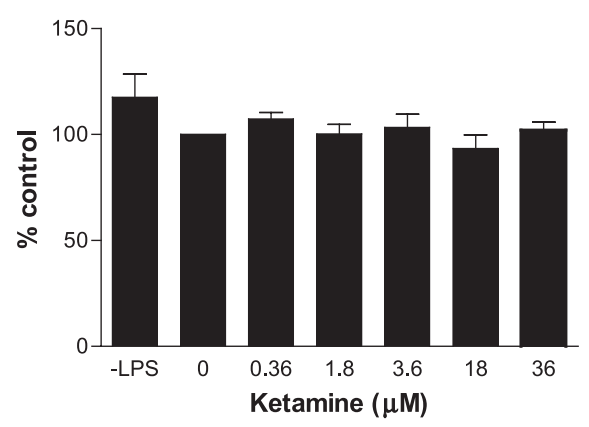

Figure 1. The influence of ketamine on LPS-induced (A) TNF- $\alpha$ (4 h), (B) TNF- $\alpha$ (24 h), (C) IL-6 $(24 \mathrm{~h})$ and (D) viability $(24 \mathrm{~h})$ in eCAS cells after exposure to LPS and ketamine, or ketamine alone (-LPS). Data expressed as mean $\pm \mathrm{SD}, n=4$. * Indicates data are statistically different from LPS alone $(p<0.05)$.

one-way analysis of variance (ANOVA), followed by a post hoc Bonferroni multiple comparison test. Lipopolysaccharide alone was regarded as a positive control and set at $100 \%$. The values were considered significantly different to control values when $p<0.05$.

\section{RESULTS}

\subsection{Effect of ketamine on LPS-induced cytokine response in eCAS cells}

In eCAS cells, TNF- $\alpha$ concentrations were significantly decreased by ketamine concentrations of 18 and $36 \mu \mathrm{M}$, compared to LPS alone following $4 \mathrm{~h}$ of incubation (Fig. 1A). After $24 \mathrm{~h}$, a significant decrease in TNF- $\alpha$ concentration was also observed with 10-fold lower ketamine concentrations (Fig. 1B). Data indicate that ketamine significantly suppresses the IL-6 concentrations in a dose-dependent manner (0.36$36 \mu \mathrm{M}$ ), compared to the control (Fig. 1C). Neither TNF- $\alpha$ nor IL- 6 data exhibited a true dose-response relationship. In the absence of LPS, ketamine had no effect on TNF- $\alpha$ and IL- 6 formation. Moreover, data obtained with the $\mathrm{AB}$ assay demonstrated that cell viability was not significantly influenced under the given experimental conditions (Fig. 1D). 

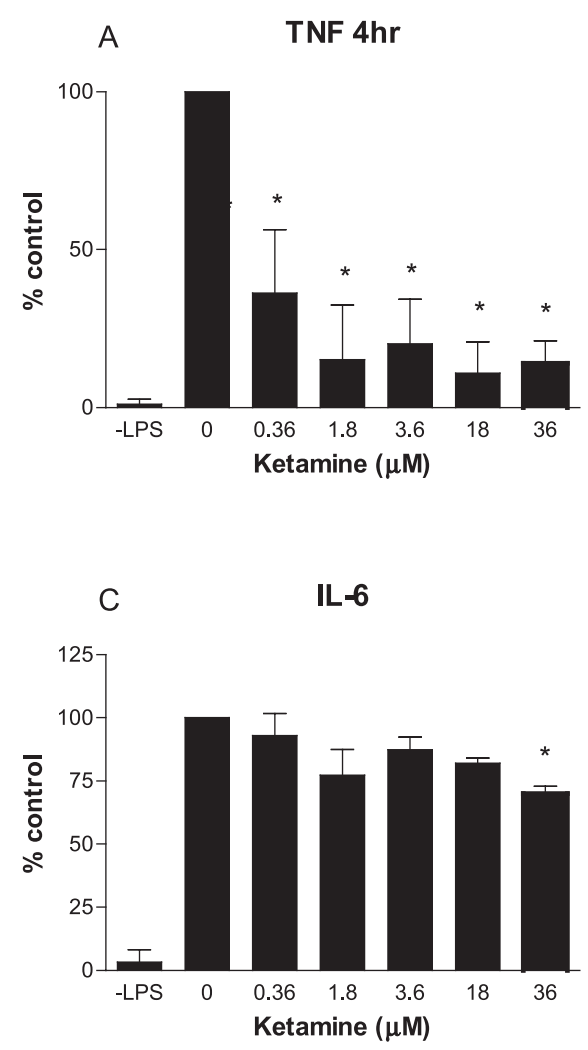

B

TNF 24hr
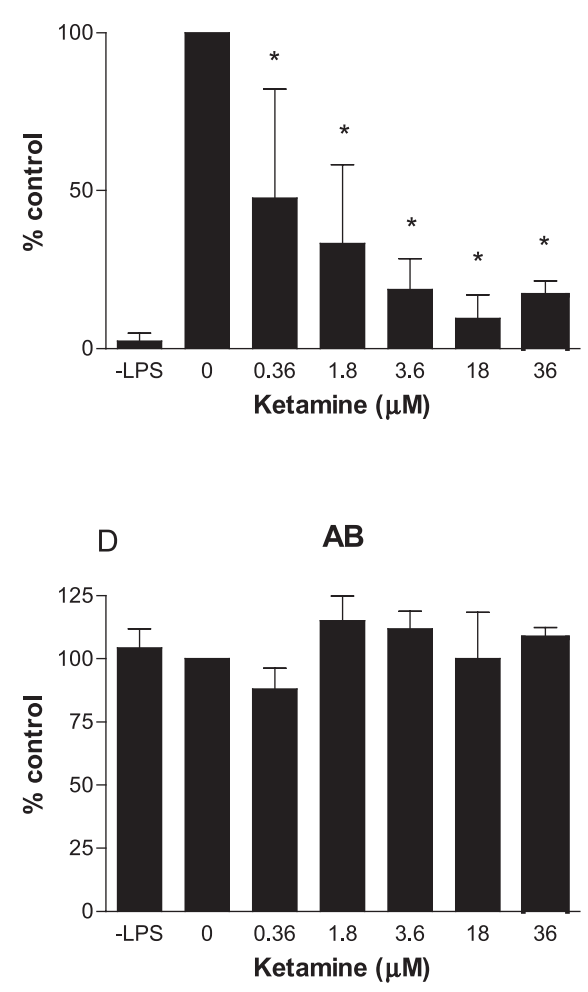

Figure 2. The influence of ketamine on LPS-induced (A) TNF- $\alpha$ (4 h), (B) TNF- $\alpha$ (24 h), (C) IL-6 $(24 \mathrm{~h})$ and (D) viability (24 h) in U937 cells after exposure to LPS and ketamine, or ketamine alone (-LPS). Data expressed as mean $\pm \mathrm{SD}, n=4 . *$ Indicates data are statistically different from LPS alone $(p<0.05)$.

\subsection{Effect of ketamine on LPS-induced cytokine response in $\mathrm{U} 937$ cells}

In U937 cells, after both 4 and $24 \mathrm{~h}$ of incubation, TNF- $\alpha$ concentrations were significantly decreased by ketamine treatment (Figs. 2A and 2B), although data did not exhibit a true dose-response relationship. At $24 \mathrm{~h}$ after incubation, ketamine significantly decreased IL-6 concentration only at $36 \mu \mathrm{M}$ (Fig. 2C). Ketamine alone had no effect on TNF- $\alpha$ and IL- 6 formation. Again, no loss of cell viability was observed following $24 \mathrm{~h}$ exposure to ketamine (Fig. 2D).

\section{DISCUSSION}

In the present study the effect of ketamine on the cytokines TNF- $\alpha$ and IL- 6 was investigated since these cytokines have been shown to play a pivotal role in the pathogenesis, progress and outcome of equine endotoxaemia $[1,9]$.

Ketamine was selected as a drug to be investigated for a variety of reasons. Ketamine is frequently used in equine anaesthetic procedures, both per- and postoperatively [11]. As a N-methyl-D-aspertate (NMDA) receptor antagonist, ketamine provides somatic 
analgesia even at subanaesthetic doses [14]. Its observed visceral analgesic properties make it specifically indicated for horses suffering from gastrointestinal disorders. Moreover, ketamine preserves cardiovascular function [14]. Hence, its use is indicated in horses suffering from endotoxaemia. Although other anaesthetic agents used in equine anaesthesia, such as barbiturates and volatile anaesthetics, have been shown to suppress the LPS-induced cytokine response in other species $[4,7]$, ketamine has been most widely studied in different species.

The ketamine concentrations used in this study were selected in consideration of the plasma level of $5 \mu \mathrm{g} / \mathrm{mL}(18 \mu \mathrm{M})$ following the IV induction dose of $2.2 \mathrm{mg} / \mathrm{kg} \mathrm{BW}$ commonly used in horses [18]. The ketamine dose range tested was aimed at determining the minimal effective concentration that suppresses the TNF- $\alpha$ response. This is of clinical relevance since lower plasma concentrations are desirable in the postoperative period to circumvent the anaesthetic and excitatory effects of ketamine.

To avoid the use of in vivo challenge experiments and due to known species difference in the LPS response, an equine macrophage cell line was used. A cell line was chosen rather than primary cells, since it has the advantage of a more uniform response pattern [20]. The well-established human macrophage derived cell line (U937 cells) was used as a reference.

This study demonstrates that ketamine suppresses LPS-induced TNF- $\alpha$ concentration in both eCAS and U937 cells in a dosedependent manner, although a true doseresponse relationship could not be established. These results correlate with ex vivo studies carried out in human blood cells [5] and murine peritoneal macrophages [15]. However, in the present investigation, inhibition of cytokine concentration was achieved at lower ketamine concentrations, which could be due to a higher sensitivity of the equine cells to ketamine.

The effect of ketamine on IL-6 concentrations was only evident in eCAS cells, since no consistent significant decrease in the U937 cells could be demonstrated. This latter finding correlates with data from a human whole blood assay described by Larsen et al. [7], where ketamine failed to significantly inhibit IL-6 production following LPS exposure, although TNF- $\alpha$ was decreased. In contrast, Weigand and colleagues [19] showed a significant decrease in IL-6 concentration in human whole blood following ketamine treatment, albeit at 30fold higher concentrations $(100-1000 \mu \mathrm{M})$. The discrepancies observed between equine and human macrophage cell lines in IL-6 suppression strengthen the necessity to conduct experiments with cells derived from the animal species under consideration.

The mechanism by which ketamine suppresses cytokine concentration has not been defined in this study. However, recent research has shown that ketamine decreases cytokine formation by reducing nuclear factor kappa B (NF- $\kappa-\mathrm{B}$ ) activation in rats [21]. Since NF- $\kappa-B$ is the major transcription factor triggering cytokine production, its inhibition leads to a decrease in cytokine formation.

In conclusion, this study demonstrates that ketamine inhibits the LPS-induced TNF- $\alpha$ and IL- 6 response in a dose-dependent manner in an equine macrophage cell line even at subanaesthetic concentrations. These results suggest a potential role for ketamine in the treatment of equine patients suffering from gastrointestinal disorders and subsequent endotoxaemia.

\section{REFERENCES}

[1] Barton M.H., Collatos C., Tumor necrosis factor and interleukin- 6 activity and endotoxin concentration in peritoneal fluid and blood of horses with acute abdominal disease, J. Vet. Intern. Med. 13 (1999) 457-464.

[2] Bertoni G., Improved bioassay for the detection of porcine tumor necrosis factor using a homologous cell line: PK (15), J. Immunol. Methods 160 (1993) 267-271. 
[3] Bull S., Langezaal I., Clothier R., Coecke S., A genetically engineered cell-based system for detecting metabolism-mediated toxicity, Altern. Lab. Anim. 29 (2001) 703-716.

[4] Giraud O., Seince P.F., Rolland C., Lecon-Malas V., Desmonts J.M., Aubier M., Dehoux M., Halothane reduces the early lipopolysaccharide-induced lung inflammation in mechanically ventilated rats, Am. J. Respir. Crit. Care Med. 162 (2000) 2278-2286.

[5] Kawasaki T., Ogata M., Kawasaki C., Ogata J., Inoue Y., Shigematsu A., Ketamine suppresses proinflammatory cytokine production in human whole blood in vitro, Anesth. Analg. 89 (1999) 665-669.

[6] Kohrs R., Durieux M.E., Ketamine: teaching an old drug new tricks, Anesth. Analg. 87 (1998) 1186-1193.

[7] Larsen B., Hoff G., Wilhelm W., Buchinger H., Wanner G.A., Bauer M., Effect of intravenous anesthetics on spontaneous and endotoxin-stimulated cytokine response in cultured human whole blood, Anesthesiology 89 (1998) 1218-1227.

[8] Morris D.D., Endotoxemia in horses: a review of cellular and humoral mediators involved in its pathogenesis, J. Vet. Intern. Med. 5 (1991) 167-181.

[9] Morris D.D., Crowe N., Moore J.N., Moldawer L.L., Endotoxin-induced production of interleukin 6 by equine peritoneal macrophages in vitro, Am. J. Vet. Res. 53 (1992) 1298-1301.

[10] Mosman T., Rapid colorimetric assay for cellular growth and survival: application to proliferation and cytotoxicity assays, J. Immunol. Methods 65 (1983) 55-63.

[11] Muir W.W., Sams R., Effects of ketamine infusion on halothane minimal alveolar concentration in horses, Am. J. Vet. Res. 53 (1992) 1802-1806.

[12] Muir W.W., Skarda R.T., Milne D.W., Evaluation of xylazine and ketamine hydrochlo- ride for anesthesia in horses, Am. J. Vet. Res. 38 (1977) 195-201.

[13] Okada H., Detection of Interleukin-1 and Interleukin- 6 on cryopreserved bovine mammary epithelial cells in vitro, J. Vet. Med. Sci. 59 (1997) 503-507.

[14] Reves J.G., Glass P.S.A., Lubarsky D.A., Nonbarbiturate intravenous anesthetics, in: Miller R.D. (Ed.), Anesthesia, Churchill Livingstone, New York, 2000, pp. 228-272.

[15] Takenaka I., Ogata M., Koga K., Matsumoto T., Shigematsu A., Ketamine suppresses endotoxin-induced tumor necrosis factor alpha production in mice, Anesthesiology 80 (1994) 402-408.

[16] Taniguchi T., Shibata K., Yamamoto K., Ketamine inhibits endotoxin-induced shock in rats, Anesthesiology 95 (2001) 928-932.

[17] Wang S., Yan L., Wesley R.A., Danner R.L., Nitric oxide increases tumor necrosis factor production in differentiated U937 cells by decreasing cyclic AMP, J. Biol. Chem. 272 (1997) 5959-5965.

[18] Waterman A.E., Robertson S.A., Lane J.G. Pharmacokinetics of intravenously administered ketamine in the horse, Res. Vet. Sci. 42 (1987) $162-166$.

[19] Weigand M.A., Schmidt H., Zhao Q., Plaschke K., Martin E., Bardenheuer H.J., Ketamine modulates the stimulated adhesion molecule expression on human neutrophils in vitro, Anesth. Analg. 90 (2000) 206-212.

[20] Werners A.H., Bull S., Fink-Gremmels J., Bryant C.E., Generation and characterization of an equine macrophage cell line (e-CAS cells) derived from equine bone marrow cells, Vet. Immunol. Immunopathol. 97 (2004) 65-76.

[21] Yu Y., Zhou Z., Xy J., Liu Z., Wang Y., Ketamine reduces NF-kappa-B activation and TNF-alpha production in rat mononuclear cells induced by lipopolysaccharide in vitro, Ann. Clin. Lab. Sci. 32 (2002) 292-298. 